\title{
HUBUNGAN KONFLIK KERJA KELUARGA TERHADAP MOTIVASI KERJA DENGAN DUKUNGAN SOSIAL SEBAGAI VARIABEL PEMODERASI PADA PERAWAT WANITA BALI DI RUMAH SAKIT DI BALI \\ I Ketut Yoga Adityawira, Supriyadi \\ Program Studi Psikologi, Fakultas Kedokteran, Universitas Udayana yogaadityawira@gmail.com
}

\begin{abstract}
Abstrak
Wanita Bali saat ini dihadapkan dengan berbagai macam pemenuhan peran yang kompleks. Disamping harus bekerja dan mengurus keluarga, wanita Bali juga berperan dalam mengikuti kegiatan sosial kemasyarakatan yang ada di Bali. Sehingga hal ini memunculkan konflik peran tersendiri bagi wanita Bali, salah satu konflik tersebut yaitu konflik kerja keluarga. Dampak dari konflik kerja keluarga yang dapat terjadi pada wanita Bali yaitu menurunkan motivasi kerja wanita Bali.

Ketika wanita Bali mengalami konflik, maka individu tersebut akan mencari sumber-sumber positif yang ada disekitarnya untuk mengatasi dampak konflik yang dihadapinya. Salah satu sumber positif adalah dukungan sosial. Tujuan dari penelitian yaitu untuk melihat hubungan konflik kerja keluarga terhadap motivasi kerja dengan dukungan sosial sebagai variabel pemoderasi pada perawat wanita Bali di rumah sakit di Bali. Data dianalisis menggunakan model Moderated Regression Analysis (MRA) dengan teknik uji residual melalui SPSS 17.0 for windows. Jumlah subjek pada penelitian ini 112 dengan kriteria wanita Bali yang bekerja sebagai perawat minimal satu tahun pada rumah sakit di Bali, telah menikah dan memiliki anak, serta berpendidikan minimal Sekolah Pendidikan Perawat (SPK) atau sederajat. Sampling menggunakan teknik sampling two stage cluster sampling.

Hasil analisis menunjukkan bahwa tidak terdapat hubungan konflik kerja keluarga dengan dukungan sosial sebagai variabel pemoderasi dengan informasi nilai koefisisen variabel motivasi kerja parameter beta standardized negatif yaitu $-0,143$, akan tetapi nilai probabilitasnya tidak signifikan $\mathrm{p}=0,134(\mathrm{p}>0,05)$. Dari hasil analisis diketahui bahwa dukungan sosial bukanlah variabel moderator, tetapi sebagai variabel prediktor yang mandiri.
\end{abstract}

Kata Kunci: Dukungan Sosial, Konflik Kerja Keluarga, Motivasi Kerja, Perawat wanita Bali

\begin{abstract}
Balinese women for now are faced with a variety of fulfillment of complex roles, in addition to work and take care of the family, Balinese women also have a role to follow social activities in Bali. So this raises roles conflict for Balinese women, one of that conflict is work family conflict. One of the effects from work family conflict that can occur in Balinese women is to reduce the work motivation of Balinese women.

When a Balinese woman have conflict, then the individual will be looking for a positive resources nearby to overcome the impact of that conflict. One of the positive resources is social support. The purpose of this research is to find out the correlation of work family conflict toward work motivation with social support as moderating variable. Data were analyzed using Moderated Regression Analysis (MRA) model with residual test techniques through SPSS 17.0 for Windows. The number of subjects in this research are 112 with criteria Balinese women who work as a nurse for at least one year in a hospital in Bali, married and have children also take health nursing school (SPK) or equivalent education as their minimum education. Technique sampling in this research use two stage cluster sampling

The analysis showed that there is no correlation of work family conflict toward work motivation with social support as moderating variable with information of coefficient values of work motivation parameter beta standardized negative is -0.143 , but the probability is not significant $p=0.134(p>0.05)$. From the analysis it was known that social support is not a moderator variable, but as independent predictor variable.
\end{abstract}

Keywords: Social Support, Work Family Conflict, Work Motivation, Balinese Nurse Women 


\section{LATAR BELAKANG}

Terjadinya perubahan demografi tenaga kerja yaitu meningkatnya jumlah wanita bekerja akan menimbulkan konflik-konflik tersendiri pada wanita, karena di satu sisi wanita harus bekerja dan di sisi lain wanita tersebut juga mengurus keluarga. Salah satu bentuk konflik akibat dari perubahan partisipasi wanita dalam dunia kerja adalah konflik kerja keluarga. Tekanan peran dalam pekerjaan dan tekanan peran dalam keluarga berpotensi untuk berkonflik satu sama lain dan bersifat dua arah seperti konflik dengan pekerjaan yang dipandang berdampak pada keluarga dan begitu juga sebaliknya (Minnotte, 2011). Konflik dua arah yang dimaksud yaitu konflik di pekerjaan mempengaruhi seseorang dalam berperan sebagai ibu rumah tangga, sedangkan konflik di keluarga mempengaruhi peran seseorang dalam bekerja. Greenhaus dan Parasuraman (1992) mengemukakan bahwa konflik kerja keluarga terjadi karena karyawan berusaha untuk menyeimbangkan antara permintaan dan tekanan yang timbul, baik dari keluarga maupun yang berasal dari pekerjaannya.

Konflik kerja keluarga semakin banyak diperbincangkan mengingat meningkatnya partisipasi wanita dalam dunia kerja. Menurut Sutanto (dalam Kussudyarsana \& Soepatini, 2008) partisipasi wanita dalam dunia kerja meningkat dari tahun ke tahun disebabkan oleh dua faktor, yaitu faktor ekonomi dan faktor non-ekonomi. Sebagai salah satu negara sedang berkembang, di Indonesia tingkat partisipasi angkatan kerja wanita juga senantiasa mengalami peningkatan, yaitu dari 48,08 persen pada tahun 2006 menjadi 50,28 persen pada tahun 2013 (BKKBN, 2014). Konflik kerja keluarga akan muncul terhadap seorang pekerja wanita, terutama jika pasangan tersebut bekerja. Pasangan suami istri yang keduanya bekerja telah meningkatkan hubungan ketergantungan antara pekerjaan dan keluarga. Hal ini di didukung oleh penelitian yang dilakukan Greenhaus dan Beutell (1985) yang menemukan bahwa suami yang ikut bekerja akan memiliki sedikit waktu untuk keluarga, yang dapat menimbulkan waktu yang berat kepada istri dikarenakan harus meluangkan waktu yang lebih dalam mengurus keluarga.

Kondisi ini akan menciptakan terjadinya konflik antara tuntutan pekerjaan dan keluarga atau yang disebut konflik kerja keluarga. Frone, Russell, dan Cooper (1992) mendefinisikan bahwa konflik kerja keluarga sebagai konflik peran yang terjadi pada karyawan, dimana di satu sisi karyawan harus melakukan pekerjaan di kantor dan di sisi lain harus memperhatikan keluarga secara utuh, sehingga sulit membedakan antara pekerjaan mengganggu keluarga dan keluarga mengganggu pekerjaan.

Timbulnya sebuah konflik biasanya terjadi pada saat seseorang berusaha memenuhi tuntutan peran dalam pekerjaan dan usaha tersebut dipengaruhi oleh kemampuan orang yang bersangkutan untuk memenuhi tuntutan keluarganya, atau sebaliknya, pemenuhan tuntutan peran dalam keluarga dipengaruhi oleh kemampuan orang tersebut dalam memenuhi tuntutan pekerjaannya (Frone, dkk., 1992). Menurut Ahmad (2008) terdapat tiga faktor yang dapat mempengaruhi terjadinya konflik kerja keluarga pada individu, yaitu (1) faktor-faktor yang berkatian dengan pekerjaan (job related factors), didefinisikan sebagai faktor yang terkait dengan karakteristik pekerjaan antara lain tipe pekerjaan (job type), komitmen waktu bekerja (job time commitment), keterlibatan pekerjaan (job involvement), peran yang melebihi kemampuan (role overload), dan fleksibilitas kerja (work flexibility), (2) faktor-faktor yang berkatian dengan keluarga (family related factors), didefinisikan sebagai faktor yang terkait dengan aspek-aspek di dalam struktur keluarga yang terkait dengan konflik kerja keluarga itu sendiri seperti tanggung jawab untuk melakukan pengasuhan. Aspek-aspek yang terkait dengan faktor-faktor yang berkatian dengan keluarga antara lain jumlah anak yang dimiliki, tahapan perkembangan kehidupan, keterlibatan dalam keluarga, dan pengasuhan anak, (3) faktorfaktor yang berkatian dengan individu (individual related factors), yaitu faktor yang terkait aspek-aspek individual yang turut berkonstribusi terhadap terjadinya konflik kerja keluarga. Faktor-faktor yang berkatian dengan individu ini antara lain nilai-nilai dalam pemenuhan peran (life role values), orientasi gender dalam menjalan peran (gender role orientation), evaluasi diri (self evaluation), dan kepribadian.

Aycan (2008) juga menyebutkan bahwa konflik kerja keluarga juga dipengaruhi oleh faktor budaya. Budaya memegang peranan penting karena membuat perbedaan penyebab dan dampak konflik kerja keluaga pada satu budaya dengan budaya lainnya. Konflik peran kerja keluarga (workto-family) lebih dirasakan oleh individu yang tinggal dalam budaya dimana keluarga merupakan hal yang penting dalam kehidupan, sedangkan konflik peran keluarga kerja (family-towork) lebih dirasakan oleh individu yang tinggal dalam budaya dimana pekerjaan merupakan hal yang penting dalam kehidupan.

Menurut Greenhaus dan Beutell (1985) konflik kerja keluarga mempunyai tiga dimensi, yaitu (1) konflik berdasar waktu (time based conflict), adalah konflik yang terjadi karena waktu yang digunakan untuk memenuhi satu peran tidak dapat digunakan untuk memenuhi peran lainnya. Individu yang mengalami konflik kerja keluarga pada tataran ini tidak bisa melaksanakan kedua peran yang dimiliki dalam waktu yang bersamaan. Konflik berdasar waktu dapat terjadi dalam dua bentuk, yaitu (a) tuntutan waktu dari peran yang satu membuat individu secara fisik tidak dapat memenuhi ekspektasi dari peran yang lain, (b) adanya tuntutan waktu yang dapat membuat individu terokupasi dengan peran yang satu di saat individu seharusnya memenuhi tuntutan peran yang lain. (2) konflik berdasar tegangan (strain based conflict), adalah konflik yang terjadi karena ketegangan yang dihasilkan oleh 
salah satu peran membuat individu sulit untuk memenuhi tuntutan peran yang lain. Ketegangan yang muncul akibat menjalankan salah satu peran mempengaruhi performa atau kinerja individu pada peran lainnya, dan (3) konflik berdasar perilaku (behavior based conflict), adalah konflik yang muncul ketika suatu tingkah laku efektif untuk satu peran namun tidak efektif digunakan untuk peran yang lain. Maka, perilaku-perilaku yang diharapkan muncul pada saat menjalankan peran yang satu bertentangan dengan ekspektasi dari peran lainnya.

Keadaan seperti ini menjadi isu yang semakin penting untuk diperhatikan oleh perusahaan baik di negara maju maupun berkembang. Hal ini didukung oleh pernyataan Greenhaus, Callanan, dan Godshalk (2000) yang menyatakan bahwa konflik kerja keluarga dapat menjadi salah satu penyebab tingginya tingkat mangkir kerja dan tingginya tingkat stress, kedua hal tersebut dapat mempengaruhi produktivitas dari sebuah organisasi. Karyawan akan berusaha menyeimbangkan tuntutan antara pekerjaan dan keluarga mereka, salah satunya dengan cara membuat jarak pada karir mereka untuk untuk mencapai kualitas hidup yang baik (quality of life) (Greenhaus, Callanan, \& Godshalk, 2000). Kondisi ini menggambarkan bahwa konflik kerja keluarga merupakan suatu determinan kehidupan yang perlu mendapat perhatian serius bukan saja dari individu yang mengalaminya, melainkan juga oleh organisasi yang mempekerjakan karyawan, terutama individu yang berasal dari keluarga dengan pasangan bekerja (dual earner family).

Greenhaus, Callanan, dan Godshalk (2000) mengatakan bahwa konflik kerja keluarga lebih dirasakan oleh wanita dibandingkan pria, dikarenakan wanita memiliki tanggung jawab yang lebih besar untuk mengurus kegiatan rumah tangga dan merawat anak dari pada pria. Biasanya tekanan lebih dirasakan oleh wanita, terutama yang telah menjadi istri dan $\mathrm{ibu}$, hal ini terjadi karena adanya kecenderungan di masyarakat yang menganggap wanita lebih mempunyai tanggung jawab untuk hal-hal yang bersifat internal dalam keluarga seperti memasak dan mengurus keluarga, sedangkan pria bertanggung jawab memenuhi peran publik dengan menjadi pekerja yang sukses (Abbot, Cieri, \& Ivelson, 1998).

Salah satu provinsi di Indonesia yang mengalami peningkatan jumlah wanita bekerja dari tahun ke tahun adalah provinsi Bali. Jumlah wanita bekerja di Bali di tahun 2010 tercatat sebanyak 867.441 orang, kemudian meningkat menjadi 967.030 orang di tahun 2011, dan telah mencapai 978.567 orang di tahun 2012 (Badan Pusat Statistik, 2013). Peningkatan jumlah wanita bekerja ini seiring pula dengan aktivitas ekonomi wanita di Bali yang ternyata jauh lebih tinggi dibandingkan dengan wanita secara nasional dan ditunjukkan melalui angka Tingkat Partisipiasi Angkatan Kerja (TPAK) yang lebih tinggi dibandingkan TPAK wanita secara nasional selama tiga periode sensus penduduk yaitu 1990, 2000, dan 2010. TPAK provinsi Bali mencapai 52,52\%, $63,06 \%$ dan 70,16\% sedangkan TPAK wanita secara nasional yang menunjukkan angka lebih rendah yaitu 38,79 \%, 43,98\% dan 51,76\% (Marhaeni, 2011).

Fakta-fakta tersebut menguatkan pernyataan Wedari (2006) bahwa wanita Bali yang merupakan bagian dari wanita bekerja di Bali, telah berani mendobrak kebiasaan bekerja. Konflik yang rentan terjadi terhadap wanita Bali dikarenakan selain memiliki tanggung jawab untuk mengurus kebutuhan rumah tangga, wanita Bali juga dituntut untuk dapat membantu perekonomian keluarga untuk mencukupi kebutuhan hidup dari keluarganya. Peranan wanita Bali tidak saja ditunjukkan dalam hal mengurusi keluarganya dan bekerja tetapi wanita Bali memiliki tanggung jawabnya sebagai pelaksana dan penyelenggara ritual Hindu yang berlangsung di lingkup keluarga dan sosial masyarakatnya. Sebagai bagian dari implementasi adat dan budaya Bali yang dijiwai nilai-nilai Hindu, maka wanita Bali biasanya disibukkan dengan aktivitas membuat sesajen atau banten untuk dipersembahkan kepada para Dewa dan Sang Hyang Widhi Wasa, disamping kewajibannya sehari-hari (Suryani, 2003). Di dalam budaya Bali, wanita juga sering dibebani dengan tugas lain, seperti ngayah banjar, yaitu kegiatan sosial yang berupa kerja sosial di wilayah tempat tinggal. Kompleksnya peran yang dimiliki oleh wanita Bali dalam pemenuhan tanggung jawab untuk mengurus kebutuhan rumah tangga, bekerja, dan mengurus kegiatan keagamaannya, sehingga wanita Bali rentan terhadap konflik yang dialaminya terkait berbagai macam peran yang harus dijalaninya.

Berdasarkan data Badan Pusat Statistik provinsi Bali dapat diketahui bahwa sejumlah wanita Bali mulai ditemukan bekerja pada sektor formal $(36,95 \%)$, meskipun jumlah wanita Bali yang bekerja di sektor informal masih lebih banyak (52,99\%) (Badan Pusat Statistik Provinsi Bali, 2013). Penggolongan ke dalam sektor formal adalah individuindividu yang bekerja sebagai pegawai kantor pemerintah maupun swasta, dan juga mereka yang berusaha dengan bantuan buruh tetap atau dibayar, sedangkan yang masuk ke dalam kategori pekerja di sektor informal adalah pekerja dengan penghasilan tidak tetap dan jenis pekerjaan ini relatif mudah untuk dimasuki karena tidak membutuhkan persyaratan yang ketat. Wanita yang bekerja di sektor formal seringkali dihadapkan dengan konflik antar peran yang disebabkan oleh kompleksitas peran kehidupan yang dimiliki (Sunasri, 2003). Wanita Bali yang bekerja di sektor formal dihadapkan pada sejumlah tantangan untuk menyelesaikan pekerjaannya di tempat kerja dengan baik tanpa mengabaikan pemenuhan peran kehidupan mereka sebagai wanita Bali yang secara kultural kompleks.

Salah satu pekerjaan dalam sektor formal adalah perawat. Perawat merupakan salah satu pekerjaan yang rentan 
mengalami konflik yang berkaitan dengan kerja dan keluarga, perawat yang berperan dalam pemberian pelayanan kesehatan mengemban tugas serta peranan yang berat, perawat juga mengemban tugas seorang ibu di keluarganya dan juga harus melayani pasien di rumah sakit. Hal ini di dukung dari berbagai penelitian yang peneliti temukan terkait konflik kerja keluarga yang dialami oleh perawat, penelitian yang dilakukan Ruwanti dan Jacobus (2013) yang meneliti tentang konflik antara pekerjaan dan keluarga serta stress kerja terhadap kinerja perawat wanita pada rumah sakit bethesda Yogyakarta menemukan hasil adanya hubungan negatif antara konflik pekerjaan dan keluarga terhadap kinerja perawat wanita, yang artinya semakin tinggi konflik pekerjaan dan keluarga, maka akan menurunkan kinerja perawat wanita. Susanti dan Ekayati (2013) dalam penelitiannya yang berjudul peran pekerjaan, peran keluarga, dan konflik pekerjaan pada perawat wanita menemukan bahwa peran pekerjaan dan peran keluarga memiliki hubungan yang positif terhadap terjadinya konflik kerja keluarga yang dialami perawat wanita, yang artinya semakin tinggi peran pekerjaan dan peran keluarga maka potensi terjadinya konflik kerja keluarga pada perawat wanita juga semakin tinggi.

Konflik-konflik tersebut akan menghambat proses pelaksanaan suatu pekerjaan pada wanita yang bekerja, karena konflik yang dihadapi dapat menyebabkan seseorang tidak dapat berfungsi secara normal dan menjadi tidak seimbang (Mansfield, Koch, Henderson, Vicary, Cohen, \& Young, 1991). Ellis dan Harley (dalam Pratopo, 2001) mendefinisikan perawat adalah orang yang merawat, memelihara, dan menjaga orang yang membutuhkan karena sakit.

Pelayanan keperawatan merupakan pelayanan utama yang harus dilakukan untuk mencapai kesembuhan pasien yang dirawat. Kesembuhan pasien yang dirawat di rumah sakit sangat ditunjang oleh peranan perawat dalam pemberian pelayanan kesehatan berupa asuhan keperawatan, pendidikan terhadap pasien mengenai hal-hal yang menunjang kesehatan dan mempercepat penyembuhan penyakit (Zaidin, 2001). Peran dan fungsi seorang perawat dituntut untuk memiliki keahlian, pengetahuan, dan konsentrasi yang tinggi. Faktanya, sekarang masih bisa kita temui perawat yang kurang memuaskan dalam memberikan pelayanan keperawatan, terutama dalam hal keramahan dan pemberian pelayanan prima. Untuk menilai sejauh mana perawat telah menjalankan tanggung jawab dan untuk memberikan umpan balik bagi perawat, rumah sakit perlu melakukan pengukuran terhadap motivasi kerja perawat. Aamodt (2010) mengatakan bahwa karyawan yang memiliki motivasi kerja rendah, maka akan memiliki kepercayaan diri yang rendah dan kebutuhan akan pencapaian prestasi yang rendah juga. Kepercayaan diri yang rendah dan kebutuhan akan pencapaian prestasi yang rendah secara otomatis dapat menurunkan tingkat kualitas dan produktivitas kerja rumah sakit secara keseluruhan sehingga akan berdampak pada penurunan pendapatan rumah sakit, hal ini terjadi karena minat masyarakat untuk memilih rumah sakit tersebut sebagai tempat berobat menjadi menurun.

Dalam dunia keperawatan sangat di butuhkan motivasi kerja dalam memberikan suatu pelayanan kesehatan, karena pekerjaan seorang perawat sangatlah berat, dari satu sisi seorang perawat harus menjalankan tugas yang menyangkut keselamatan atau kelangsungan hidup pasien yang harus dirawatnya. Disisi lain keadaan psikologis perawat juga harus tetap terjaga, karena pelayanan keperawatan yang diberikan oleh perawat meliputi pelayanan jasa keperawatan. Jika kondisi fisik, emosional, dan mental perawat kurang baik maka hal ini akan berdampak pada pelayanan keperawatan yang diberikan pada pasien. Pieter (dalam Limonu, 2013) menyatakan bahwa salah satu faktor yang mempengaruhi perilaku seseorang adalah motivasi. Munandar (2001) mengatakan bahwa motivasi adalah suatu proses dimana kebutuhan-kebutuhan mendorong seseorang untuk melakukan serangkaian kegiatan yang mengarah ke tercapainya tujuan tertentu. Jelaslah bahwa motivasi yang menjadi dasar utama bagi seseorang memasuki berbagai organisasi adalah dalam rangka usaha orang yang bersangkutan memuaskan berbagai kebutuhannya, baik yang bersifat politik, ekonomi, sosial dan berbagai kebutuhan lainnya yang semakin kompleks.

Adanya motivasi kerja yang tinggi pada karyawan akan membuat karyawan bekerja dengan giat untuk melaksanaakan pekerjaannya, tetapi jika motivasi kerja rendah maka sebaliknya membuat karyawan tidak dapat unjuk kerja dalam melaksanakan pekerjaannya (Munandar, 2001). Kanfer, Chen, dan Pritchard (2008) mendefinisikan motivasi kerja adalah proses psikologis yang mempengaruhi usaha seseorang dan sumber-sumber yang dimilikinya untuk beraksi di tempat kerja, termasuk arah, intensitas, dan ketekunan dalam melakukan aksinya tersebut. Menurut teori kebutuhan McClelland (dalam Robbins \& Judge, 2008) dimensi motivasi kerja dapat dilihat dari tiga kebutuhan yang dimiliki individu, yaitu (a) kebutuhan pencapaian (Need for Achievement) adalah dorongan untuk melebihi, mencapai standar-standar, dan berusaha keras untuk berhasil. (b) kebutuhan kekuatan (Need for Power) adalah kebutuhan untuk membuat individu lain berperilaku sedemikian rupa sehingga mereka tidak akan berperilaku sebaliknya. (c) kebutuhan hubungan (Need for Affliation) adalah keinginan untuk menjalin suatu hubungan antarpersonal yang ramah dan akrab. Konflik kerja keluarga pada perawat yang muncul bersifat sementara tetapi mempengaruhi hampir keseluruhan aspek kehidupannya. Sehingga konflik kerja keluarga memiliki potensi signifikan untuk melemahkan perawat untuk memberikan layanan berkualitas tinggi.

Konflik kerja keluarga dapat menyebabkan ketidakmauan karyawan untuk mendedikasikan diri secara lebih pada pekerjaan (Li, Zhong, Chen, Xie \& Mao, 2014) dan 
menurunkan konsentrasi bekerja (Artiawati, 2004). Kehilangan konsentrasi dan semangat selama bekerja serta ketidakmauan untuk mendedikasikan diri pada pekerjaan telah menjadi suatu indikator bahwa karyawan dalam hal ini perawat memiliki motivasi kerja yang rendah. Semakin berkonflik, maka motivasi kerja perawat wanita Bali menjadi rendah dalam menjalani pekerjaannya di rumah sakit di Bali.

Konflik kerja keluarga yang dialami oleh perawat wanita Bali ini akan mempengaruhi perawat dalam bidang pekerjaannya. Konflik antara tanggung jawab pekerjaan dan keluarga dapat mengakibatkan rendahnya kepuasan kerja, meningkatkan mangkir kerja, menurunkan motivasi karyawan, dan dalam jangka waktu tertentu dapat mengakibatkan perpindahan karyawan (Triaryati, 2003). Penelitian yang dilakukan Rahmadita (2013) menemukan hasil bahwa terdapat hubungan negatif antara konflik peran ganda dan motivasi kerja, ketika konflik peran ganda tinggi maka motivasi kerja pada karyawati menurun. Penelitian lain yang dilakukan Soeharto (2010) menemukan hasil hubungan negatif konflik kerja keluarga dengan kepuasan kerja. Melalui hasil penelitian-penelitian tersebut dapat diambil kesimpulan bahwa memang konflik kerja keluarga sangat mempengaruhi pekerjaan yang dilakukan oleh wanita, dalam konteks ini yaitu perawat wanita Bali yang bekerja di rumah sakit di Bali.

Salah satu upaya untuk mengatasi dampak dari konflik kerja keluarga sehingga dapat berpengaruh ke motivasi kerja yaitu dengan menggunakan sumber-sumber positif yang ada di sekitar individu, salah satunya adalah dukungan sosial. Menurut Uchino (dalam Sarafino \& Smith, 2011) dukungan sosial mengacu ke perasaan nyaman, perhatian, penghargaan atau bantuan yang di dapat dari individu lain atau grup. Sarafino dan Smith (2011) mengatakan bahwa dukungan sosial dapat berasal dari banyak sumber, seperti orang yang dicintai, keluarga, teman, psikiater atau psikolog, komunitas, dan organisasi. Menurut Sarafino dan Smith (2011) dukungan sosial memiliki empat tipe, yaitu (a) dukungan emosional atau dukungan menghargai (emotional or esteem support) mengandung arti pertolongan perasaan empati, perhatian, melihat individu secara positif dan mendukung orang lain. Dukungan ini memunculkan perasaan nyaman, tenang, rasa memiliki dan dicintai. (b) dukungan berwujud atau dukungan instrumental (tangible or instrumental support) mengandung arti pertolongan secara langsung kepada individu, seperti individu memberi atau meminjamkan uang atau bantuan untuk membantu orang lain terhadap pekerjaan atau aktifitasnya. (c) dukungan informasi (informational support) mengandung arti saran, arahan, anjuran, atau umpan balik mengenai apa yang orang lain sedang lakukan. (d) dukungan persahabatan (companionship support) mengandung arti bagaimana ketersediaan individu untuk menghabiskan waktu dengan orang lain, dengan cara melakukan aktifitas sosial secara bersama-sama.
Menurut Broman (dalam Taylor, 2003) dukungan sosial bisa efektif dalam mengatasi masalah tekanan psikologis pada masa sulit dan menekan. Hal tersebut dikarenakan dukungan sosial dapat membuat individu menyadari bahwa ada lingkungan terdekat individu baik itu keluarga atau teman yang siap membantu individu dalam menghadapi tekanan. Adanya dukungan sosial dapat membuat individu menyadari bahwa ada lingkungan terdekat individu yang siap membantu individu dalam menghadapi tekanan. Dukungan sosial yang diberikan seperti rasa empati, pemberian semangat, kasih sayang dan apresiasi akan membantu individu ketika mengalami permasalahan. Dukungan ini membantu individu dalam membangun harga diri, kompetensi, dan rasa percaya dirinya. Hal ini sejalan dengan hasil penelitian yang dilakukan oleh Christyoadi, Sukarti dan Suseno (2009) yang menemukan hasil bahwa ada hubungan positif yang signifikan antara dukungan sosial dengan motivasi kerja pada karyawan. Dukungan sosial merupakan faktor sosial di luar individu yang dapat meningkatkan kemampuan menghadapi masalah. Salah satu faktor penyebab menurunnya motivasi kerja karena tidak adanya dukungan sosial yang menyebabkan motivasi kerja akan cenderung menurun pada para karyawan yang tidak mendapat dukungan dari lingkungan sosial.

Individu yang memperoleh dukungan sosial kemungkinan akan memiliki motivasi kerja yang lebih tinggi daripada yang tidak memperoleh dukungan sosial. Menurut Johnson (dalam Ruwaida, Lilik, \& Dewi, 2006) dukungan sosial dapat meningkatkan motivasi sehingga mengurangi dampak stres dan meningkatkan produktivitas. Menurut Johnson dan Johnson (1991) ada empat manfaat dukungan sosial, yaitu dukungan sosial dihubungkan dengan pekerjaan akan meningkatkan produktivitas, meningkatkan kesejahteraan psikologis dan penyesuaian diri dengan memberikan rasa memiliki, memperjelas identitas diri, menambah harga diri serta mengurangi stres, meningkatkan dan memelihara kesehatan fisik serta pengelolaan terhadap stress dan tekanan.

Penelitian yang dilakukan oleh Walen dan Lachman (dalam Gatari, 2008) menunjukkan bahwa dukungan sosial dapat menjelaskan sebagian besar varian pada kepuasan hidup dan afek positif, serta memprediksi afek negatif yang rendah pada orang dewasa. Penelitian yang dilakukan oleh Gatari (2008) menunjukkan bahwa dukungan sosial mempunyai hubungan yang positif dengan kepuasan hidup dan afek menyenangkan, sedangkan berhubungan negatif dengan afek tidak menyenangkan pada ibu bekerja. Bagi seorang wanita Bali yang berprofesi sebagai perawat sekaligus sebagai ibu rumah tangga, dukungan sosial dapat membuat perasaannya menjadi tentram dan dapat mengurangi beban yang dirasakan. Jika individu diterima dan dihargai secara positif, maka individu tersebut cenderung dapat mengelola konflik yang dialaminya dengan baik dan ketika melakukan suatu aktifitas 
seperti bekerja maka dapat memunculkan motivasi yang tinggi dalam bekerja. Sehingga hal tersebut dapat bermanfaat bagi dirinya dan perusahaan tempat individu tersebut bekerja.

Berdasarkan pemaparan di atas peneliti tertarik untuk meneliti hubungan konflik kerja keluarga terhadap motivasi kerja dengan dukungan sosial sebagai variabel pemoderasi pada perawat wanita Bali di rumah sakit di Bali. Motivasi kerja perawat Bali menjadi hal yang menarik untuk diteliti di tengah konflik penyeimbangan peran yang dialami oleh wanita Bali, dan melalui adanya dukungan sosial yang diterima perawat Bali, konflik peran tersebut dapat diminimalisir sehingga dapat mempengaruhi motivasi kerja perawat Bali. Disamping itu, mengingat secara kultural peran yang dimiliki wanita Bali sangatlah kompleks. Ringkasnya, fokus dari penelitian ini adalah untuk melihat hubungan antara konflik kerja keluarga terhadap motivasi kerja dengan dukungan sosial sebagai variabel pemoderasi pada perawat wanita Bali di rumah sakit di Bali dan untuk mengetahui apakah dukungan sosial mempunyai peran sebagai moderator atau tidak, serta untuk mengetahui pengaruh dukungan sosial apakah memperkuat atau memperlemah hubungan antara konflik kerja keluarga dengan motivasi kerja.

\section{METODE}

\section{Variabel dan Definisi Operasional}

Variabel penelitian adalah suatu atribut atau sifat atau nilai dari orang, obyek atau kegiatan yang mempunyai variasi tertentu yang ditetapkan oleh peneliti untuk dipelajari dan kemudian ditarik kesimpulannya (Sugiyono, 2014). Penelitian ini menggunakan beberapa jenis variabel, yaitu (1) variabel bebas merupakan variabel yang mempengaruhi atau yang menjadi sebab perubahannya atau timbulnya variabel terikat (Sugiyono, 2014). Variabel bebas pada peneltian ini adalah konflik kerja keluarga. Greenhaus dan Beutell (1985) mendefinisikan konflik kerja keluarga sebagai suatu bentuk konflik antar peran, tekanan-tekanan peran pekerjaan dan keluarga saling tidak selaras satu sama lain dalam beberapa hal, partisipasi dalam salah satu peran tersebut menjadi lebih sulit dikarenakan tuntutan untuk berpartisipasi dalam peran yang lain. Tuntutan pekerjaan berhubungan dengan tekanan yang berasal dari beban kerja yang berlebihan dan waktu seperti pekerjaan yang harus diselesaikan terburu-buru dan deadline. Sedangkan tuntutan keluarga berhubungan dengan waktu yang dibutuhkan untuk menangani tugas-tugas rumah tangga.

Frone dkk., (1992) mendefinisikan konflik kerja keluarga sebagai konflik peran yang terjadi pada karyawan, dimana di satu sisi karyawan harus melakukan pekerjaan di kantor dan di sisi lain harus memperhatikan keluarga secara utuh, sehingga sulit membedakan antara pekerjaan mengganggu keluarga dan keluarga mengganggu pekerjaan.
Pekerjaan mengganggu keluarga, artinya sebagian besar waktu dan perhatian dicurahkan untuk melakukan pekerjaan sehingga kurang mempunyai waktu untuk keluarga. Sebaliknya keluarga mengganggu pekerjaan berarti sebagian besar waktu dan perhatiannya digunakan untuk menyelesaikan urusan keluarga sehingga mengganggu pekerjaan. Konflik kerja keluarga ini terjadi ketika kehidupan rumah seseorang berbenturan dengan tanggung jawabnya di tempat kerja, seperti masuk kerja tepat waktu, menyelesaikan tugas harian, atau kerja lembur. Demikian juga tuntutan kehidupan rumah yang menghalangi seseorang untuk meluangkan waktu untuk pekerjaannya atau kegiatan yang berkaitan dengan kariernya. Sependapat dengan Frone, (Greenhaus \& Parasuraman, 1992) mengemukakan bahwa konflik kerja keluarga terjadi karena karyawan berusaha untuk menyeimbangkan antara permintaan dan tekanan yang timbul, baik dari keluarga maupun yang berasal dari pekerjaannya.

(2) Variabel tergantung merupakan variabel yang dipengaruhi atau yang menjadi akibat, karena adanya variabel bebas (Sugiyono, 2014). Variabel tergantung pada penelitian ini adalah motivasi kerja. Munandar (2001) mengatakan bahwa motivasi adalah suatu proses dimana kebutuhankebutuhan mendorong seseorang untuk melakukan serangkaian kegiatan yang mengarah ke tercapainya tujuan tertentu. Herlambang dan Murwani (2012) mendefinisikan motivasi sebagai dorongan (misalnya ide, emosi, atau kebutuhan fisik) yang menyebabkan seseorang mengambil suatu tindakan. Sedangkan motivasi kerja memiliki definisi yang berbeda. Robbins dan Judge (2008) mendefinisikan motivasi kerja sebagai proses yang menjelaskan intensitas, arah, dan ketekunan seorang indvidu untuk mencapai tujuan organisasi. Menurut Kanfer, Chen, dan Pritchard (2008) motivasi kerja adalah proses psikologis yang mempengaruhi usaha seseorang dan sumber-sumber yang dimilikinya untuk beraksi di tempat kerja, termasuk arah, intensitas, dan ketekunan dalam melakukan aksinya tersebut.

(3) Variabel moderator adalah variabel yang mempengaruhi (memperkuat dan memperlemah) hubungan antara variabel bebas dengan variabel tergantung (Sugiyono, 2014). Variabel moderator pada penelitian ini adalah dukungan sosial. Dukungan sosial diartikan sebagai pertukaran interpersonal yang dicirikan oleh perhatian emosi, bantuan instrumental, penyediaan informasi atau pertolongan lainnya (Taylor dkk., 2009). Menurut Dunkel-Schetter dan Bennett (dalam Baumeister \& Bushman, 2011) dukungan sosial secara umum dapat didefinisikan sebagai bantuan emosional, informasional, atau instrumental yang didapat dari orang lain. Menurut Uchino (dalam Sarafino \& Smith, 2011) dukungan sosial mengacu ke perasaan nyaman, perhatian, penghargaan atau bantuan yang di dapat dari individu lain atau grup. Individu dengan dukungan sosial yakin bahwa mereka dicintai, dihargai, dan merasa menjadi bagian dari lingkungan 
sosial, seperti keluarga atau komunitas yang dapat memberikan bantuan kepada individu ketika dibutuhkan (Sarafino \& Smith, 2011).

\section{Populasi dan Sampel Penelitian}

Dalam penelitian ini, peneliti terlebih dahulu menentukan populasi penelitian. Populasi adalah wilayah generalisasi yang terdiri atas obyek atau subyek yang mempunyai kualitas dan karakteristik tertentu yang ditetapkan oleh peneliti untuk dipelajari dan kemudian ditarik kesimpulannya (Sugiyono, 2014). Populasi yang ditargetkan dalam penelitian ini adalah semua perawat wanita Bali yang bekerja di rumah sakit di Bali. Karakteristik sampel dalam penelitian ini, yaitu (a) perawat yang telah berkeluarga dan memiliki anak. Konteks berkeluarga yang dimaksud dalam hal ini adalah telah menikah dan telah memiliki anak. Alasan pemilihan subjek dengan karakteristik ini agar subjek memiliki peran pekerjaan dan peran keluarga. (b) perawat memiliki masa kerja minimal satu tahun. Alasan pemilihan subjek dengan masa kerja minimal satu tahun karena perawat yang bekerja di rumah sakit Bali sudah menjadi karyawan tetap di rumah sakit tersebut, ketika perawat telah menjadi karyawan tetap pada rumah sakit, perawat akan memiliki jam tetap dalam melakukan pekerjaannya sehingga nantinya akan menimbulkan tekanan-tekanan dalam pemenuhan perannya, berbeda dengan perawat kontrak yang memiliki jam yang lebih fleksibel yang lebih dapat mengatur pemenuhan peran lainnya, dikarenakan jam kerja yang lebih fleksibel.

(c) Perawat wanita Bali. Alasan pemilihan subjek dengan karakteristik ini dikarenakan wanita Bali memiliki peran juga untuk melaksanakan peran pada tugas-tugas keagamaannya sehingga konflik yang dimiliki wanita Bali cenderung lebih kompleks. Sebagai bagian dari implementasi adat dan budaya Bali yang dijiwai nilai-nilai Hindu, maka wanita Bali biasanya disibukkan dengan aktivitas membuat sesajen atau banten untuk dipersembahkan kepada para dewa dan Sang Hyang Widhi Wasa, disamping kewajibannya sehari-hari (Suryani, 2003). (d) Bekerja di rumah sakit di Bali. Alasan pemilihan karakteristik ini dikarenakan perawat yang bekerja di rumah sakit memiliki tuntutan-tuntutan yang lebih, salah satunya adalah waktu kerja, berbeda halnya dengan perawat yang bekerja di klinik yang memiliki waktu kerja yang lebih fleksibel. Contohnya perawat yang bekerja di rumah sakit harus bekerja pada hari libur, berbeda halnya pada perawat yang bekerja di klinik yang dapat mendapat menggunakan waktu libur untuk pemenuhan peran lain. (e) bependidikan minimal Sekolah Perawat Kesehatan (SPK) atau sederajat di bidang keperawatan. Alasan pemilihan karakteristik ini dikarenakan menurut Peraturan Menteri Kesehatan Republik Indonesia No. 17 Tahun 2013 Pasal 1, untuk menjadi seorang perawat individu harus lulus pendidikan perawat baik di dalam maupun di luar negeri sesuai dengan peraturan perundang-undangan, dalam hal ini pendidikan yang dimaksud di dalam negeri salah satunya adalah bependidikan minimal Sekolah Perawat Kesehatan (SPK) atau sederajat di bidang keperawatan.

Sampel penelitian diambil dengan metode pengambilan sampel secara acak dengan menggunakan two stage cluster sampling, yaitu merupakan teknik pengambilan sampel dengan dua tahap pengambilan sampling dari kelompok-kelompok unit-unit yang kecil, atau cluster. Sampling tahap pertama yaitu memilih cluster dari clustercluster yang ada. Sampling tahap kedua yaitu memilih unit elementer dari berbagai unit elementer yang ada dalam cluster yang telah terpilih pada sampling tahap pertama (Nazir, 1988). Populasi penelitian ini terletak di Provinsi Bali yang terdiri dari 8 kabupaten yaitu Gianyar, Tabanan, Klungkung, Bangli, Badung, Jembrana, Buleleng, Karangasem dan 1 kotamadya yaitu Denpasar diposisikan menjadi cluster populasi penelitian. Di setiap kabupaten dan kotamadya tersebut terdapat sejumlah rumah sakit. Berbagai macam rumah sakit tersebut diposisikan sebagai unit elementer dalam cluster tersebut.

Dalam proses pengambilan sampel, kesembilan area tersebut diundi secara acak sampai akhirnya terpilih satu kabupaten atau kotamadya. Kemudian, dilakukan pengundian secara acak yang kedua terhadap berbagai rumah sakit yang terdapat di kabupaten atau kotamadya terpilih hingga akhirnya terpilih satu rumah sakit untuk mewakili sampel. Artinya semua perawat wanita Bali yang sesuai dengan karakteristik sampel, yang bekerja pada rumah sakit tersebut terpilih sebagai sampel penelitian. Jika jumlah sampel perawat tidak memenuhi sampel minimal, maka peneliti memilih satu rumah sakit lagi dengan teknik yang sama.

\section{Metode Pengambilan Data}

Pengambilan data dalam penelitian ini dilakukan melalui pembagian kuesioner kepada responden penelitian. Kuesioner merupakan teknik pengumpulan data yang dilakukan dengan cara memberi seperangkat pertanyaan atau pernyataan tertulis kepada responden untuk dijawabnya (Sugiyono, 2014). Kuesioner menggunakan Skala Likert.

Skala Likert digunakan untuk mengukur sikap, pendapat, dan persepsi seseorang atau sekelompok orang mengenai fenomena sosial (Sugiyono, 2014). Skala disajikan dalam bentuk pernyataan favorable dan unfavorable. Skor yang diberikan bergerak dari 1 sampai 4. Bobot penilaian untuk favorable yaitu: Sangat Tidak Setuju (STS) $=1$, Tidak Setuju $(\mathrm{TS})=2$, Setuju $(\mathrm{S})=3$, Sangat Setuju $(\mathrm{SS})=4$, sedangkan bobot penilaian untuk pernyataan unfavorable yaitu: Sangat Tidak Setuju (STS) $=4$, Tidak Setuju $(T S)=3$, Setuju $(S)=2$, Sangat Setuju $(S S)=1$. Pengukuran variabel konflik kerja keluarga, dilakukan dengan memodifikasi skala konflik kerja keluarga yang dibuat oleh Kesumaningsari 
(2014) berdasarkan teori yang dikemukakan oleh Greenhaus dan Beutell (1985) yang terdiri dari aspek-aspek time based conflict, strain based conflict, dan behavior based conflict. Skala ini memiliki nilai reliabilitas ( $\alpha$ ) 0,944 dengan validitas aitem bergerak dari angka 0,353 sampai dengan 0,782 (Kesumaningsari, 2014).

Modifikasi skala yang dilakukan oleh peneliti yaitu mengurangi jumlah aitem pada skala untuk menghindari subjek merasa kelelahan pada saat menjawab serta ada perubahan kata-kata dalam skala dikarenakan perbedaan subjek yang digunakan oleh peneliti. Contohnya indikator kegiatan bermasyarakat mengganggu jam kerja pada dimensi time based conflict yang digunakan oleh (Kesumaningsari, 2014) tidak digunakan oleh peneliti, dikarenakan jika menggunakan kegiatan bermasyarakat mengganggu jam kerja, maka konflik yang dimaksud adalah konflik budaya dengan konflik kerja, sedangkan dalam penelitian ini yang digunakan oleh peneliti adalah konflik kerja dengan konflik keluarga. Subjek yang digunakan oleh peneliti adalah perawat, sedangkan subjek yang digunakan oleh Kesumaningsari (2014) adalah karyawan, dikarenakan perbedaan subjek, peneliti melakukan perubahan kata-kata dalam skala yang dimodifikasi.

Pengukuran variabel motivasi kerja, dilakukan dengan memodifikasi skala motivasi kerja yang dibuat oleh Putra (2013) berdasarkan teori yang dikemukakan oleh David McClelland (dalam Robbins dan Judge, 2008) yang terdiri dari tiga kebutuhan yaitu, kebutuhan pencapaian, kebutuhan kekuatan dan kebutuhan hubungan. Skala ini memiliki nilai reliabilitas $(\alpha)$ 0,857 dengan validitas aitem bergerak dari angka 0,206 sampai dengan 0,573 (Putra, 2013). Modifikasi skala yang dilakukan oleh peneliti yaitu mengurangi jumlah aitem pada skala untuk menghindari subjek merasa kelelahan pada saat menjawab serta ada perubahan kata-kata dalam skala dikarenakan perbedaan subjek yang digunakan oleh peneliti. Contohnya indikator suka mengambil pekerjaan dengan resiko moderat pada dimensi kebutuhan pencapaian oleh (Putra, 2013) tidak digunakan oleh peneliti, dikarenakan peneliti tidak mengetahui ukuran yang digunakan Putra (2013) untuk melihat bahwa suatu pekerjaan dapat dikategorikan memiliki resiko yang rendah, moderat, atau tinggi. Subjek yang digunakan oleh peneliti adalah perawat, sedangkan subjek yang digunakan oleh Putra (2013) adalah karyawan, dikarenakan perbedaan subjek, peneliti melakukan perubahan kata-kata dalam skala yang dimodifikasi.

Pengukuran variabel dukungan sosial menggunakan skala dukungan sosial yang dibuat oleh peneliti berdasarkan teori yang dikemukakan oleh Sarafino dan Smith (2011) yang terdiri dari empat tipe, yaitu Emotional or Esteem support, Tangible or Instrumental support, Informational support dan Companionship support.

\section{Metode Analisis Data}

Metode analisis data yang digunakan adalah analisis statistik dan untuk menganalisis data penelitian yang telah diperoleh menggunakan model Moderated Regression Analysis (MRA) atau regresi dengan variabel moderasi dengan teknik uji residual dan dibantu dengan program analisis statistik komputer yaitu SPSS 17.0 for windows. Analisis regresi dengan variabel moderasi dipilih sebagai metode analisis data di dalam penelitian ini karena dapat menganalisis apakah kehadiran variabel moderasi berpengaruh terhadap hubungan yang terjadi antara variabel bebas pertama dan variabel tergantung (Sarwono, 2013). Menurut Yudiatmaja (2003) analisis regresi dengan variabel moderasi digunakan untuk menjawab apakah variabel moderator dapat memoderasi hubungan kausal antara variabel bebas terhadap variabel tergantung. Sebelum melakukan analisis data, peneliti melakukan uji asumsi data penelitian, yaitu dengan melakukan uji normalitas dan uji linieritas.

Uji normalitas digunakan untuk menguji apakah dalam model regresi, variabel pengganggu memiliki distribusi normal (Ghozali, 2005a). Dalam penelitian ini peneliti menggunakan Komogorov-Smirnov (K-S). Menurut (Santoso, 2003) data disebut berdistribusi normal apabila signifikansi (p) pada Komogorov-Smirnov (K-S) lebih besar dari 0,05 ( $>0,05)$. Uji distribusi normal dalam penelitian ini menggunakan bantuan SPSS. Uji linieritas digunakan untuk menguji apakah spesifikasi yang digunakan sudah benar atau tidak dan juga melihat bentuk hubungan antara variabel bebas dengan variabel terikat. Uji linieritas dilakukan dengan bantuan SPSS dengan menggunakan uji lagrange multiplier dengan membandingkan nilai $\mathrm{c}^{2}$ hitung dengan $\mathrm{c}^{2}$ tabel. Apabila nilai $\mathrm{c}^{2}$ hitung lebih kecil dari $\mathrm{c}^{2}$ tabel $\left(\mathrm{c}^{2}\right.$ hitung $<\mathrm{c}^{2}$ tabel) maka dapat dikatakan bahwa data linier (Ghozali, 2005b).

\section{Hipotesis Penelitian}

Uji hipotesis dilakukan untuk melihat terbukti atau tidaknya hipotesis yang diajukan peneliti. Uji hipotesis penelitian ini menggunakan taraf signifikansi $5 \%$ atau 0,05 . Apabila nilai signifikansi di bawah $0,05(\mathrm{p}<0,05)$, maka $\mathrm{H}_{0}$ ditolak yang artinya variabel bebas dan variabel tergantung memiliki hubungan yang signifikan. Apabila nilai signifikansi di atas $0,05(\mathrm{p}>0,05)$, maka $\mathrm{H}_{0}$ diterima yang artinya variabel bebas dan variabel tergantung tidak memiliki hubungan yang signifikan (Sugiyono, 2012).

Berdasarkan uraian teoritis di atas, maka dapat diajukan hipotesis sebagai berikut:

\section{Hipotesis Nol}

$\mathrm{H}_{0}$ : Tidak terdapat hubungan konflik kerja keluarga terhadap motivasi kerja dengan dukungan sosial sebagai variabel pemoderasi pada perawat wanita Bali di rumah sakit di Bali 


\section{Hipotesis Alternatif}

Ha : Terdapat hubungan konflik kerja keluarga terhadap motivasi kerja dengan dukungan

sosial sebagai variabel pemoderasi pada perawat wanita Bali di rumah sakit di Bali

\section{HASIL PENELITIAN}

Pada penelitian ini, peneliti menggunakan analisis dengan model Moderated Regression Analysis (MRA) dengan teknik uji residual atau regresi dengan variabel moderasi dengan teknik uji residual, data penelitian harus mampu melewati dua syarat dasar yaitu uji normalitas dan uji linieritas. Kedua uji tersebut perlu dilakukan untuk mengetahui distribusi normal dan linieritas data penelitian. Uji normalitas bertujuan untuk menguji apakah dalam model regresi, variabel pengganggu atau residual memiliki distribusi normal (Ghozali, 2005b). Penelitian ini melakukan uji normalitas dengan menggunakan uji Kolmogorov-Smirnov (K-S). Peneliti melihat nilai residual pada variabel konflik kerja keluarga motivasi kerja dan dukungan sosial apakah mengikuti distribusi normal menggunakan uji KolmogorovSmirnov (K-S).

Hasil uji normalitas menunjukkan bahwa besarnya nilai Kolmogorov-Smirnov (K-S) adalah 0,691 dan signifikansi pada 0,726 hal ini berarti data residual pada variabel konflik kerja keluarga, variabel motivasi kerja dan variabel dukungan sosial memiliki signifikansi $0,726(\mathrm{p}>0,05)$ yang berarti data residual pada ketiga variabel tersebut berdistribusi normal. Uji linieritas dilakukan untuk melihat apakah data pada variabel yang akan dikorelasikan bersifat linier atau tidak. Uji linieritas dilakukan dengan bantuan SPSS dengan menggunakan uji lagrange multiplier dengan membandingkan nilai $\mathrm{c}^{2}$ hitung dengan $\mathrm{c}^{2}$ tabel. Apabila nilai $\mathrm{c}^{2}$ hitung lebih kecil dari $\mathrm{c}^{2}$ tabel $\left(\mathrm{c}^{2}\right.$ hitung $<\mathrm{c}^{2}$ tabel) maka dapat dikatakan bahwa data linier (Ghozali, 2005b). Melalui uji lagrange multiplier ditemukan hasil $c^{2}$ hitung adalah 0 sedangkan $\mathrm{c}^{2}$ tabel 137,701. Jadi dapat dikatakan bahwa $\mathrm{c}^{2}$ hitung $<\mathrm{c}^{2}$ tabel, sehingga dapat dikatakan data bersifat linier.

Uji hipotesis dilakukan untuk menguji hipotesis penelitian ini yaitu dukungan sosial memoderasi hubungan antara konflik kerja keluarga dan motivasi kerja pada perawat wanita Bali dengan menggunakan model Moderated Regression Analysis (MRA) atau regresi dengan variabel moderasi dengan teknik uji residual dengan bantuan SPSS. Analisis moderasi yang dilakukan oleh peneliti kali ini dilakukan dengan metode Moderated Regression Analysis (MRA) dengan teknik uji residual. Moderated Regression Analysis (MRA) dengan teknik uji residual merupakan analisis dengan menguji pengaruh deviasi (penyimpangan) dari suatu model. Fokusnya adalah ketidak cocokkan (lack of fit) yang dihasilkan dari deviasi hubungan linier antar variabel independen. ketidak cocokkan (lack of fit) ditunjukkan oleh nilai residual didalam regresi (Ghozali, 2005b).

Berbeda dengan dua cara lain yang menguji variabel moderasi yaitu uji interaksi dan uji selisih nilai mutlak yang kecenderungan akan terjadi multikolinieritas yang tinggi antar variabel dan hal ini akan menyalahi asumsi klasik dalam regresi Ordinary Least Square (OLS), untuk mengatasi multikolinieritas ini, maka dikembangkan teknik uji residual (Ghozali, 2005a).

Hasil analisis model Moderated Regression Analysis (MRA) dengan teknik uji residual dapat dilihat pada tabel 1 .

$$
\text { Tabel } 1
$$

Hasil Uji Dukungan Sosial sebagai Variabel Moderator

Coefficients $^{2}$

\begin{tabular}{|c|c|c|c|c|c|c|}
\hline & \multicolumn{3}{|c|}{ - } & \multirow[b]{3}{*}{$\mathrm{T}$} & \multirow[b]{3}{*}{ Sig. } \\
\hline & & $\begin{array}{c}\text { Unstandardized } \\
\text { Coefficients }\end{array}$ & & $\begin{array}{l}\text { Standardized } \\
\text { Coefficients }\end{array}$ & & \\
\hline \multicolumn{2}{|c|}{ Model } & $\begin{array}{c}\mathrm{B} \\
\end{array}$ & Std. Error & Beta & & \\
\hline \multirow[t]{2}{*}{1} & (Constant) & 6.946 & 3.205 & & 2.167 & .032 \\
\hline & $\begin{array}{l}\text { Motivasi } \\
\text { Kerja }\end{array}$ & -.086 & .057 & -.143 & -1.510 & .134 \\
\hline
\end{tabular}

a. Dependent Variable: AbsRes_1

Dari hasil analisis model Moderated Regression Analysis (MRA) dengan teknik uji residual diketahui bahwa nilai koefisisen variabel motivasi kerja parameter beta standardizednya negatif yaitu $-0,143$, akan tetapi nilai probabilitasnya tidak signifikan $\mathrm{p}=0,134(\mathrm{p}>0,05)$. Maka dapat disimpulkan bahwa variabel dukungan sosial bukanlah variabel moderator, akan tetapi variabel dukungan sosial sebagai variabel prediktor yang mandiri. Dukungan sosial dapat menjadi variabel moderator jika nilai koefisisen variabel motivasi kerja parameter beta standardizednya negatif dan nilai probabilitasnya signifikan (Ghozali, 2005b). Sehingga hipotesis penelitian $\left(\mathrm{H}_{0}\right)$ diterima yaitu tidak terdapat hubungan konflik kerja keluarga terhadap motivasi kerja dengn dukungan sosial sebagai variabel pemoderasi pada perawat wanita Bali di rumah sakit di Bali.

Hasil Uji Signifikansi Parameter Kemandirian Konflik Kerja Keluarga terhadap Dukungan Sosial

\begin{tabular}{|c|c|c|c|c|c|c|}
\hline \multicolumn{7}{|c|}{ Coefficients $^{\mathrm{a}}$} \\
\hline & & $\begin{array}{l}\text { Unstandardized } \\
\text { Coefficients }\end{array}$ & & $\begin{array}{l}\text { Standardized } \\
\text { Coefficients }\end{array}$ & & \\
\hline \multicolumn{2}{|c|}{ Model } & B & Std. Error & Beta & $\mathrm{t}$ & Sig. \\
\hline 1 & (Constant) & 65.034 & 2.219 & & 29.314 & .000 \\
\hline & Konflik Kerja & -.367 & .045 & -.611 & -8.087 & .000 \\
\hline
\end{tabular}

a. Dependent Variable: Dukungan Sosial

Seberapa jauh hubungan konflik kerja keluarga secara individual dalam menerangkan variasi variabel dukungan sosial dapat dijelaskan melalui hasil uji signifikansi parameter kemandirian. Melalui tabel 2 dapat dilihat pula arah hubungan yang terjadi dan apakah hubungan yang terjadi merupakan hubungan yang bersifat sebab akibat (Ghozali, 2005b). Arah hubungan antara konflik kerja keluarga dengan dukungan sosial dapat dilihat dari nilai standardized beta (B) bertanda negatif ( $\mathrm{B}=-0,611)$. Tanda negatif $(-)$ berarti bahwa kedua 
variabel memiliki hubungan yang berkebalikan. Semakin tinggi tingkat konflik kerja keluarga maka tingkat dukungan sosial akan semakin rendah, begitu pula sebaliknya, apabila semakin rendah tingkat konflik kerja keluarga, maka tingkat dukungan sosial akan semakin tinggi.

Nilai probabilitas (p) pada taraf signifikansi 5\% yang terdapat pada tabel uji signifikansi pada tabel 2 menunjukkan angka $0,000(p<0,05)$ artinya konflik kerja keluarga memiliki hubungan yang signifikan dengan dukungan sosial, dimana gejala konflik kerja keluarga yang berhubungan dengan gejala dukungan sosial dapat juga dikatakan sebagai suatu gejala sebab akibat. Hubungan ini diyakini sebagai gejala sebab akibat dan bukan merupakan gejala random karena dapat meramalkan apabila terjadi kenaikan 1 nilai pada variabel dukungan sosial, maka nilai konflik kerja keluarga akan turun sebanyak 0,611 atau setiap penurunan 0,611 konflik kerja keluarga dapat meningkatkan 1 nilai pada dukungan sosial. Hal ini dapat diketahui dari fungsi persamaan garis regresi $\mathrm{Y}=$ $\mathrm{a}+\mathrm{bX}$ untuk variabel konflik kerja keluarga dan dukungan sosial yaitu $\mathrm{Y}=65,034+(-0,611)$ konflik kerja keluarga.

Melalui hasil uji signifikansi parameter kemandirian, dapat disimpulkan bahwa terdapat hubungan yang negatif dan signifikan antara konflik kerja keluarga dengan dukungan sosial. Hubungan yang terjadi antara kedua variabel penelitian bersifat negatif kausal dan bukan merupakan gejala random.

Tabel 3

Hasil Uji Signifikansi antara Konflik Kerja Keluarga dan Dukungan Sosial terhadap Motivasi Kerja

\begin{tabular}{|c|c|c|c|c|c|c|}
\hline \multicolumn{7}{|c|}{ Coefficients $^{\mathrm{a}}$} \\
\hline & & $\begin{array}{c}\text { Unstandardized } \\
\text { Coefficients }\end{array}$ & & $\begin{array}{c}\text { Standardized } \\
\text { Coefficients } \\
\end{array}$ & & \\
\hline \multicolumn{2}{|c|}{ Model } & B & Std. Error & Beta & $\mathrm{t}$ & Sig. \\
\hline \multirow[t]{3}{*}{1} & (Constant) & 45.705 & 7.280 & & 6.278 & .000 \\
\hline & $\begin{array}{l}\text { Konflik Kerja } \\
\text { Keluarga }\end{array}$ & -.130 & .063 & -.212 & -2.046 & .043 \\
\hline & Dukungan Sosial & .360 & .105 & .355 & 3.416 & .001 \\
\hline
\end{tabular}

Seberapa jauh hubungan konflik kerja keluarga dan dukungan sosial secara bersamaan dalam menerangkan variasi motivasi kerja dapat dijelaskan melalui hasil uji signifikansi pada tabel 3. Melalui tabel ini dapat dilihat pula arah hubungan yang terjadi dan apakah hubungan yang terjadi merupakan hubungan yang bersifat sebab akibat (Ghozali, 2005b). Arah hubungan antara konflik kerja keluarga dengan motivasi kerja dapat dilihat dari nilai standardized beta (B) bertanda negatif ( $\mathrm{B}=-0,212)$. Sedangkan arah hubungan antara dukungan sosial dengan motivasi kerja dapat dilihat dari nilai standardized beta $(\mathrm{B})$ bertanda positif $(\mathrm{B}=+0,355)$. Tanda negatif (-) berarti bahwa kedua variabel memiliki hubungan yang berkebalikan. Semakin tinggi tingkat konflik kerja keluarga maka tingkat motivasi kerja akan semakin rendah, begitu pula sebaliknya, apabila semakin rendah tingkat konflik kerja keluarga, maka tingkat motivasi kerja akan semakin tinggi. Sedangkan tanda positif (+) berarti bahwa kedua variabel memiliki hubungan yang searah. Semakin tinggi dukungan sosial maka tingkat motivasi kerja akan semakin tinggi, begitu pula sebaliknya, apabila semakin rendah tingkat dukungan sosial, maka tingkat motivasi kerja akan rendah juga.

Nilai probabilitas (p) pada taraf signifikansi 5\% yang terdapat pada tabel uji signifikansi parameter kemandirian menunjukkan angka 0,043 ( $\mathrm{p}<0,05)$ pada variabel konflik kerja keluarga dan angka $0,001(\mathrm{p}<0,05)$ pada variabel dukungan sosial artinya konflik kerja keluarga dan dukungan sosial memiliki hubungan yang signifikan dengan motivasi kerja, dimana gejala konflik kerja keluarga dan gejala dukungan sosial yang berhubungan dengan gejala motivasi kerja dapat juga dikatakan sebagai suatu gejala sebab akibat. Hubungan ini diyakini sebagai gejala sebab akibat dan bukan merupakan gejala random karena dapat meramalkan apabila terjadi kenaikan 1 nilai pada variabel motivasi kerja, maka nilai konflik kerja keluarga akan turun sebanyak 0,212 dan meningkatkan nilai dukungan sosial sebanyak 0,355 atau setiap kenaikan 0,355 dukungan sosial maka terjadi penurunan 0,212 konflik kerja keluarga dan meningkatkan 1 nilai pada motivasi kerja. Hal ini dapat diketahui dari fungsi persamaan garis regresi $\mathrm{Y}=\mathrm{a}+\mathrm{b}_{1} \mathrm{X}_{1}+\mathrm{b}_{2} \mathrm{X}_{2}$ untuk variabel konflik kerja keluarga dan dukungan sosial dengan motivasi kerja yaitu $\mathrm{Y}=$ $45,705+(-0,212)$ konflik kerja keluarga $+(0,355)$ dukungan sosial.

Melalui hasil uji signifikansi parameter, dapat disimpulkan bahwa terdapat hubungan yang negatif dan signifikan antara konflik kerja keluarga dengan motivasi kerja dan terdapat hubungan yang positif dan signifikan antara dukungan sosial dengan motivasi kerja serta hubungan yang negatif dan signifikan antara konflik kerja keluarga dengan dukungan sosial.

Hubungan yang terjadi antara konflik kerja keluarga dan dukungan sosial dengan motivasi kerja bersifat negatif kausal dan bukan merupakan gejala random sedangkan hubungan yang terjadi antara dukungan sosial dengan motivasi kerja bersifat positif kausal dan bukan merupakan gejala random.

\section{Analisis Tambahan}

Dalam penelitian peneliti melakukan analisis tambahan yang berkaitan dengan variabel penelitian ini, yaitu melihat perbedaan konflik kerja keluarga berdasarkan jumlah anak. Perbedaan konflik kerja keluarga berdasarkan jumlah anak dilakukan dengan menggunakan analisis one way anova. One way anova digunakan untuk pengujian lebih dari dua sampel (Yudiatmaja, 2013). Kategori jumlah anak dalam analisis ini dibagi menjadi 3 kelompok subjek yaitu subjek yang memiliki 1 anak, subjek yang memiliki 2 anak dan subjek yang memiliki 3 anak. Sebelum melakukan analisis one 
way anova peneliti terlebih dahulu melakukan uji normalitas menggunakan uji kolmogorov-smirnov dan uji homogenitas menggunakan uji skala variasi homogenitas melalui levene statistik.

Berdasarkan hasil analisis dengan menggunakan uji Kolmogorov-Smirnov (K-S), besarnya nilai KolmogorovSmirnov adalah 1,179 dan signifikansi pada 0,124, hal ini berarti data residual pada variabel konflik kerja keluarga dan variabel jumlah anak memiliki signifikansi $0,124 \quad(\mathrm{p}>0,05)$ yang berarti data residual pada kedua variabel tersebut berdistribusi normal. Berdasarkan hasil analisis dengan menggunakan uji skala variasi homogenitas melalui levene statistik diperoleh nilai probabilitas signifikansi sebesar 0,193 ( $p>0,05)$ yang berarti data variabel konflik kerja keluarga berdasarkan variabel jumlah anak mempunyai varian yang sama. Setelah melalui uji normalitas dan uji homogenitas bahwa data berdistribusi normal dan mempunyai varian yang sama peneliti melakukan analisis one way anova.

Tabel 4

Hasil Uji One Way Anova Perbedaan Konflik Kerja Keluarga berdasarkan Jumlah Anak

\begin{tabular}{lccccc}
\hline \multicolumn{5}{c}{ ANOVA } \\
\hline & Sum of Squares & Df & Mean Square & F & Sig. \\
\hline $\begin{array}{l}\text { Between } \\
\text { Groups } \\
\text { Within Groups }\end{array}$ & 92.871 & 2 & 46.435 & .978 & .380 \\
Total & 3940.664 & 83 & 47.478 & & \\
\hline
\end{tabular}

Berdasarkan tabel 4, dapat dilihat bahwa nilai probabilitas konflik kerja keluarga sebesar 0,380 ( $p>0,05)$. Nilai probabilitas $0,380(\mathrm{p}>0,05)$ memiliki arti bahwa tidak ada perbedaan tingkat konflik kerja keluarga yang signifikan pada perawat wanita Bali yang memiliki 1 anak, perawat wanita Bali yang memiliki 2 anak maupun perawat wanita Bali yang memiliki 3 anak.

\section{PEMBAHASAN DAN KESIMPULAN}

Hasil uji hipotesis penelitian ini adalah tidak terdapat hubungan konflik kerja keluarga terhadap motivasi kerja dengan dukungan sosial sebagai variabel pemoderasi pada perawat wanita Bali di rumah sakit di Bali. Hal tersebut berarti $\left(\mathrm{H}_{0}\right)$ penelitian ini diterima. Hasil tersebut dapat dilihat dari hasil analisis statistik yang didapat dengan menggunakan model Moderated Regression Analysis (MRA) dengan teknik uji residual.

$\left(\mathrm{H}_{0}\right)$ dalam penelitian ini yaitu tidak terdapat hubungan konflik kerja keluarga terhadap motivasi kerja dengan dukungan sosial sebagai variabel pemoderasi pada perawat wanita Bali di rumah sakit di Bali diterima. Artinya dukungan sosial sebagai variabel moderasi tidak berperan dalam meningkatkan ataupun melemahkan hubungan antara konflik kerja keluarga terhadap motivasi kerja, namun dukungan sosial berperan sebagai variabel prediktor yang mandiri.

Dukungan sosial tidak berperan sebagai variabel moderator, melainkan sebagai variabel prediktor yang mandiri, artinya bahwa variabel dukungan sosial memiliki hubungan yang bersifat langsung mandiri terhadap variabel motivasi kerja tanpa adanya variabel konflik kerja keluarga, demikian juga bahwa konflik kerja keluarga memiliki hubungan yang bersifat langsung mandiri tanpa adanya dukungan sosial. Selain itu, konflik kerja keluarga dan dukungan sosial juga dapat bersama-sama berhubungan terhadap motivasi kerja. Sebagai contoh setiap individu akan mendapat dukungan sosial tanpa harus mengalami atau memiliki konflik kerja keluarga untuk dapat berhubungan dengan variabel motivasi kerja, begitu juga setiap individu yang mengalami atau memiliki konflik kerja keluarga akan memiliki hubungan langsung yang mandiri terhadap motivasi kerja tanpa harus adanya dukungan sosial. Selain itu, konflik kerja keluarga dan dukungan sosial juga dapat berhubungan bersama-sama terhadap motivasi kerja.

Sehingga variabel dukungan sosial dapat berperan sebagai variabel prediktor mandiri yang memiliki hubungan langsung yang mandiri dengan motivasi kerja, begitu juga halnya dengan konflik kerja keluarga yang memiliki hubungan langsung yang mandiri dengan motivasi kerja serta konflik kerja keluarga dan dukungan sosial yang dapat berhubungan bersama-sama terhadap motivasi kerja.

Secara ringkas hubungan antar variabel dapat dilihat pada gambar 1 .

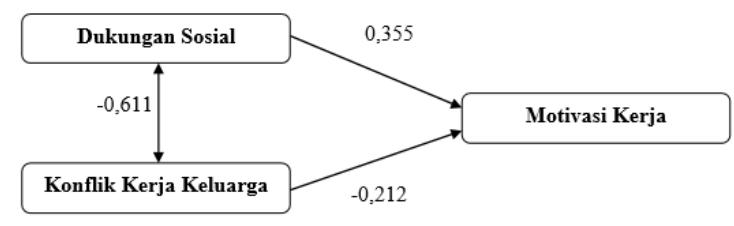

$$
\begin{gathered}
\text { Gambar l } \\
\text { Hubungan antar Variabel Hubungan Konflik Kerja Keluarga dan Dukungan Sosial } \\
\text { terhadap Motivasi Kerja }
\end{gathered}
$$

Penerimaan hipotesis ini menunjukkan bahwa konflik kerja keluarga yang dialami oleh perawat wanita Bali yang bekerja di rumah sakit di Bali memiliki hubungan dengan motivasi kerja tanpa dimoderasi oleh dukungan sosial, namun dukungan sosial berperan sebagai variabel prediktor yang mandiri serta konflik kerja keluarga dan dukungan sosial dapat secara bersama-sama berhubungan terhadap motivasi kerja perawat wanita Bali yang bekerja di rumah sakit di Bali. Suyadnya (2009) menyebutkan sejak berstatus menikah, wanita Bali tidak hanya disibukkan oleh tugas dan tanggungjawab sebagai istri dan/atau seorang ibu, namun juga disibukkan oleh tugas dan tanggungjawab dalam kehidupan sosial bermasyarakat.

Saat mencoba meyeimbangkan perannya di dalam keluarga dan pekerjaan perawat, wanita Bali tidak akan luput 
dari konflik kerja keluarga karena pemenuhan dari tuntutantuntutan peran-peran yang saling berbenturan. Konflik-konflik tersebut akan menghambat proses pelaksanaan suatu pekerjaan pada wanita yang bekerja, karena konflik yang dihadapi dapat menyebabkan seseorang tidak dapat berfungsi secara normal dan menjadi tidak seimbang (Mansfield dkk., 1991). Menurut Taylor dkk., (2009) dalam teori social role (peran sosial) yang berarti seperangkat norma sosial tentang bagaimana perilaku seharusnya dari seseorang dalam posisi sosial tertentu. Perawat wanita Bali yang berperan sebagai perawat, istri dan wanita Bali memiliki aturan dan ekspektasi bagaimana seharusnya masing-masing peran berperilaku.

Peran sebagai perawat yang mengharuskan individu bersikap ramah, santun dan sabar dalam merawat pasien, peran sebagai ibu yang mengharuskan individu penyabar dan penyayang terhadap anak dan keluarganya serta peran sebagai wanita Bali yang mengharuskan individu terlibat dalam hal adat dan keagamaan. Aturan dan ekspektasi dari peran-peran tersebut saling mempengaruhi keseimbangan individu, disamping keterbatasan individu dalam menjalani masingmasing perannya. Ketika individu tidak dapat menyeimbangkan peran-peran tersebut maka peran-peran tersebut akan tidak saling selaras sehingga menimbulkan konflik. Individu yang tidak meraih keseimbangan dalam menjalankan peran-perannya dapat kehilangan semangat untuk melakukan pekerjaannya (Parkes \& Langford, 2008). Tidak dapat meraih keseimbangan menggambarkan adanya konflik kerja keluarga yang terjadi. Tidak hanya menyebabkan hilangnya semangat, konflik kerja keluarga juga menyebabkan ketidakmauan karyawan untuk mendedikasikan diri secara lebih pada pekerjaan (Li, Zhong, Chen, Xie \& Mao, 2014) dan menurunkan konsentrasi bekerja (Artiawati, 2004).

Kehilangan konsentrasi dan semangat selama bekerja serta ketidakmauan untuk mendedikasikan diri pada pekerjaan telah menjadi suatu indikator bahwa karyawan dalam hal ini perawat memiliki motivasi kerja yang rendah. Semakin berkonflik, maka motivasi kerja perawat wanita Bali menjadi rendah dalam menjalani pekerjaannya di rumah sakit di Bali. Konflik kerja keluarga yang dialami oleh perawat wanita Bali ini akan mempengaruhi perawat dalam bidang pekerjaannya. Sesuai dengan hasil penelitian ini bahwa terdapat hubungan yang negatif dan signifikan antara konflik kerja keluarga dengan motivasi kerja. Hal ini terbukti dari nilai standardized beta (B) bertanda negatif ( $\mathrm{B}=-0,212)$ dengan nilai probabilitas menunjukkan angka $0,043(\mathrm{p}<0,05)$.

Konflik antara tanggung jawab pekerjaan dan keluarga dapat mengakibatkan rendahnya kepuasan kerja, meningkatkan mangkir kerja, menurunkan motivasi karyawan, dan dalam jangka waktu tertentu dapat mengakibatkan perpindahan karyawan (Triaryati, 2003). Penelitian yang dilakukan Rahmadita (2013) menemukan hasil bahwa terdapat hubungan negatif antara konflik peran ganda dan motivasi kerja, ketika konflik peran ganda tinggi maka motivasi kerja pada karyawati menurun. Penelitian lain yang dilakukan Soeharto (2010) menemukan hasil hubungan negatif konflik kerja keluarga dengan kepuasan kerja. Konflik kerja keluarga mempengaruhi pekerjaan juga ditunjukkan dari hasil penelitian yang dilakukan oleh Kesumaningsari (2014) yang menemukan hubungan yang negatif dan signifikan antara konflik kerja keluarga dengan keterikatan karyawan (work engagement) karyawati Bali pada bank di Bali. Melalui hasil penelitian-penelitian tersebut dapat diambil kesimpulan bahwa memang konflik kerja keluarga sangat mempengaruhi pekerjaan yang dilakukan oleh wanita, dalam konteks ini yaitu perawat wanita Bali yang bekerja di rumah sakit di Bali.

Hasil penelitian ini menunjukkan bahwa dukungan sosial tidak berperan sebagai variabel moderator, melainkan memiliki peran sebagai variabel prediktor yang mandiri, bahwa variabel dukungan sosial memiliki hubungan yang bersifat langsung mandiri terhadap variabel motivasi kerja tanpa adanya variabel konflik kerja keluarga. Hal ini terbukti dari nilai standardized beta $(\mathrm{B})$ bertanda positif $(\mathrm{B}=+0,355)$ dengan nilai probabilitas menunjukkan angka $0,001(\mathrm{p}<0,05)$ yang artinya terdapat hubungan yang positif dan signifikan antara dukungan sosial dengan motivasi kerja. Hal ini sejalan dengan penelitian yang dilakukan oleh Rahmadita (2013) yang memperoleh hasil bahwa ada hubungan positif yang sangat signifikan antara dukungan sosial pasangan dengan motivasi kerja pada karyawati. Penelitian yang dilakukan oleh Christyoadi, Sukarti dan Suseno (2009) menemukan hasil bahwa ada hubungan positif yang signifikan antara dukungan sosial dengan motivasi kerja pada karyawan.

Ketika individu mendapat dukungan sosial sepenuhnya terhadap apa yang dikerjakan, maka individu akan lebih merasa nyaman dalam bekerja sehingga individu pun akan menunjukan performansi kerja yang maksimal, yang nantinya akan meningkatkan motivasi bekerja dari indvidu tersebut. Bagi seorang wanita Bali yang berprofesi sebagai perawat sekaligus sebagai ibu rumah tangga, dukungan sosial dapat membuat perasaannya menjadi tentram dan dapat mengurangi beban yang dirasakan. Jika individu diterima dan dihargai secara positif, maka individu tersebut cenderung dapat mengelola konflik yang dialaminya dengan baik dan ketika melakukan suatu aktifitas seperti bekerja maka dapat memunculkan motivasi yang tinggi dalam bekerja.

Hasil analisis tambahan menggunakan one way anova menemukan hasil bahwa tidak ada perbedaan tingkat konflik kerja keluarga yang signifikan pada perawat wanita Bali yang memiliki 1 anak, perawat wanita Bali yang memiliki 2 anak maupun perawat wanita Bali yang memiliki 3 anak dengan nilai probabilitas $0,380(\mathrm{p}>0,05)$. Hasil penelitian ini sejalan dengan hasil penelitian yang dilakukan oleh Anjani (2015) yang menemukan bahwa tidak ada perbedaan konflik kerja keluarga berdasarkan karyawan Bali yang belum 
memiliki anak, memiliki 1 anak, memiliki 2 anak, memiliki 3 anak dan yang memiliki 4 anak. Tidak ada perbedaan tingkat konflik kerja keluarga dengan jumlah anak dapat ditinjau dari faktor budaya masyarakat Bali yang kolektivis. Kultur kolektivis lebih menekankan pada kesetiaan kepada keluarga, kepatuhan pada norma kelompok dan pemeliharaan harmoni atau kerukunan dalam hubungan sosial dengan anggota lain dalam kelompok itu (Taylor dkk., 2009).

Dikarenakan kesetiaan kepada keluarga dan pemeliharaan harmoni atau kerukunan dalam hubungan sosial dengan anggota lain dalam keluarga sehingga konflik kerja keluarga yang dimiliki dapat dikaitkan dengan faktor dukungan sosial yang diterima dari ranah keluarga. Hal ini tercermin dari pasangan yang sudah menikah dan memiliki anak masih banyak yang tinggal bersama orangtua atau keluarga besar, sehingga individu yang memiliki anak akan mendapatkan dukungan pertolongan dari orangtua atau anggota keluarga lainnya untuk menjaga dan merawat anaknya ketika individu tersebut harus bekerja.

Berdasarkan hasil analisis dan pembahasan, maka dapat ditarik kesimpulan mengenai hasil penelitian bahwa tidak terdapat hubungan konflik kerja keluarga terhadap motivasi kerja dengan dukungan sosial sebagai variabel pemoderasi pada perawat wanita Bali di rumah sakit di Bali. Dukungan sosial tidak berperan sebagai variabel moderator, melainkan sebagai variabel prediktor yang mandiri, artinya bahwa variabel dukungan sosial memiliki hubungan yang bersifat langsung mandiri terhadap variabel motivasi kerja tanpa adanya variabel konflik kerja keluarga, demikian juga bahwa konflik kerja keluarga memiliki hubungan yang bersifat langsung mandiri tanpa adanya dukungan sosial. Selain itu, konflik kerja keluarga dan dukungan sosial juga dapat bersama-sama berhubungan terhadap motivasi kerja serta tidak ada perbedaan tingkat konflik kerja keluarga yang signifikan dengan jumlah anak yang dimiliki perawat wanita Bali.

Berdasarkan kesimpulan yang telah dibuat, maka dapat disampaikan saran-saran kepada beberapa pihak, yaitu (a) kepada rumah sakit tempat perawat wanita Bali bekerja. Rumah sakit diharapkan tetap menerapkan fleksibilitas waktu kerja pada perawat wanita Bali, sehingga konflik kerja keluarga yang dialami perawat wanita Bali tetap rendah. Menurut Greenhaus, Callanan, dan Godshalk (2000) fleksibilitas waktu kerja yang ditawarkan pada karyawan akan memberikan kontrol waktu kepada karyawan sehingga mereka dapat menyeimbangkan tanggung jawab pekerjaan dan keluarga dan dapat mengurangi tingkat mangkir kerja dan tingkat perpindahan kerja, seperti yang telah diterapkan oleh rumah sakit dengan melakukan sistem kerja shift serta dengan pengaturan sistem cuti. (b) kepada perawat wanita Bali. Bagi perawat wanita Bali yang memiliki tingkat konflik kerja keluarga yang tinggi dapat melakukan coping terhadap konflik kerja keluarga yang dialaminya, salah satunya dengan menggunakan teknik coping structural role redefinition.

Menurut Greenhaus, Callanan, dan Godshalk (2000) structural role redefinition merupakan strategi coping untuk pemecahan masalah dengan merubah bagian dari lingkungan yang dapat meningkatkan konflik dan stress. Contohnya dengan membagi tugas-tugas atau pekerjaan rumah tangga, seperti perawat wanita Bali hanya bertugas memasak dan suami bertugas membersihkan rumah, dengan hal ini perawat wanita Bali dapat merubah suasana lingkungan di rumah tangga sehingga individu tidak terlalu banyak memiliki tuntutan dalam pekerjaan rumah tangga. (c) saran bagi peneliti selanjutnya. Dalam pengambilan data penelitian disarankan peneliti turut mengawasi subjek dalam pengisian skala, jika memungkinkan skala dapat di isi langsung di tempat, jika tidak memungkinkan maka skala di perbolehkan dibawa pulang oleh subjek. Pengawasan dalam pengisian skala tersebut dimaksudkan agar subjek tidak meniru pengisian skala yang di kerjakan oleh temannya.

\section{DAFTAR PUSTAKA}

Abbot, J., H, Cieri, D., \& R. D. Iverson. (1998). Costing turnover: Implication of work/family conflict at management level. Asia Pasific Journal of Human Resources, 36 (1), 25-43.

Artiawati. (2004). Work family conflict in asian cultural context: the case of Indonesia, makalah symposium Project 3535 pada International Conference Society for Industrial and Organizational Psychology, Chicago, USA. Diunduh dari http:www.workfamilyconflict.ca/cms/documents/20/Artiaw ati_SIOP_symposium.p df.

Ahmad, A. (2008). Direct and indirect effects of work-family conflict on job performance. The Journal of International Management Studies, 3(2), 176-180.

Aycan, Z. (2008). Cross-cultural perspective to work-family conflict in K.Korabik, D.S. Lero, \& D.L., whitehead, handbook of work-family integration. San Diego, CA: Elseiver.

Aamodt, M., G. (2010). Industrial/Organizational psychology. Belmont: Wadsworth Cengage Learning.

Anjani, N. M. A. S. (2015). Konflik kerja keluarga dengan kepuasan kerja yang dimoderasi komitmen organisasi pada karyawan Bali. (Skripsi tidak dipublikasikan). Program Studi Psikologi Fakultas Kedokeran Universitas Udayana, Denpasar.

Baumeister, R., F. \& Bushman, B., J. (2011). Social psychology and human nature (2nd ed.). Belmont: Cengage Learning.

Badan Pusat Statistik Provinsi Bali. (2013). Diunduh dari : Kondisi ketenaga kerjaan menurut jenis kelamin di provinsi Bali http.//www.bps.go.id/tab_sub/view.php?kat=1\&tabel=1\&.

Badan Kependudukan dan Keluarga Berencana Nasional (BKKBN). (2014). Diunduh dari :Tingkat Partisipasi Angkatan Kerja Nasional: http://www.bkkbn.go.id/kependudukan/Pages/DataSurvey/ Sakernas/Ekonomi_dan_ Ketenagakerjaan/TPAK/Nasional.aspx. 
Christyoadi, F., Sukarti, \& Suseno, M.F. (2009). Hubungan antara dukungan sosial dengan motivasi kerja karyawan PT. Usmantek Kabupaten Magelang. Naskah tidak dipublikasikan. Fakultas Psikologi dan Ilmu Sosial Budaya Universitas Islam Indonesia, Yogyakarta.

Frone, M.R., Russell, M. \& Cooper, M.L. (1992). Antecedents and outcomes of work- family conflict: testing a model of the work-family interface. Journal of Applied Psychology, 77(1), 65-78.

Greenhaus, J., H., \& Beutell, N., J. (1985). Sources of conflict between work and family roles. Journal of the Academy of Management Review, 10(1), 76-88.

Greenhaus, J.H., Callanan, G.A., \& Godshalk, V.M. (2000). Carrer management (3rd ed.). Orlando: Harcourt, Inc.

Ghozali, I. (2005a). Aplikasi analisis multivariate dengan program SPSS (Edisi 3). Semarang: Badan Penerbit Universitas Diponegoro.

Ghozali, I. (2005b). Aplikasi analisis multivariate dengan program IBM SPSS 20 (Edisi 6). Semarang: Badan Penerbit Universitas Diponegoro.

Gatari, E. (2008). Hubungan antara perceived social support dan subjective well being pada ibu bekerja. Naskah tidak dipublikasikan. Fakultas Psikologi Universitas Indonesia, Depok.

Herlambang, Susatyo \& Murwani, A. (2012). Manajemen kesehatan dan rumah sakit. Yogyakarta: Gosyen Publishing.

Johnson. D. W, \& Johnson. F. (1991) Joining together. Group theory and group skill. (4th ed.). Englewood Cliffts: Prentice Hall Inc.

Kreitner, R. \& Kinicki, A. (2001). Organizational Behavior. New York: Mc Graw Hill Companies, Inc.

Kanfer, R., Chen, G., \& Pritchard, R.,D. (2008). Work motivation past, present, and future. New York: Taylor \& Francis Group.

Kussudyarsana \& Soepatini. (2008). Pengaruh karier objektif pada wanita terhadap konflik keluarga-pekerjaan:

Kasus pada Universitas Muhammadiyah Surakarta. Jurnal Penelitian Humaniora, 9(2), 128-145.

Kesumaningsari, N. P. A. (2014). Hubungan konflik kerja-keluarga dengan work engagement karyawati Bali pada bank di Bali. (Skripsi tidak dipublikasikan). Program Studi Psikologi Universitas Udayana, Denpasar.

Limonu, F. (2013). Hubungan antara motivasi kerja dengan burnout pada perawat di IRD RSUD Dr. M.M Dundo Limboto. (Skripsi tidak dipublikasikan). Program Studi Ilmu Keperawatan Universitas Negeri Gorontalo, Gorontalo.

Li, L., Zhong, J. A., Chen, Y., Xie, Y., \& Mao, S. (2014). Moderating effects of proactive personality on factors influencing work engagement based on job-demands resources model. Social Behavior and Personality, 42(1), 7-16.

Mansfield, P. K., Koch, P. B., Henderson, J., Vicary, J. R., Cohen, M., \& Young, E. W. (1991). The job climate for women in traditionally male blue collar occupations. Journal of Sex Role, 25(1), 63-79.

Munandar, A., S. (2001). Psikologi industri dan organisasi. Jakarta: Universitas Indonesia Press.
Marhaeni. (2011). Diunduh dari : Banyak Faktor Pengaruhi Perempuan Bali Pegang Jabatan Eselon: http//ugm.ac.id/id/berita/3658-

banyak.faktor.pengaruhi.perempuan.Bali.pegang.jabatan.es elon.

Minnote, K. L. (2011). Family structure, gender, and the work-family interface: Work-to-family conflict among single and partnered parents. Department of Sociology, 33(1), 95-107.

Nazir, M. (1988). Metode penelitian. Jakarta: Ghalia Indonesia.

Parasuraman, S \& Greenhaus, J H. (1992). Role stressors, social support and well-being among two-career couples. Journal of Organizational Behavior, 13(4), 339-356.

Pratopo, T. C. (2001). Hubungan antara motivasi dengan stres kerja pada perawat RS. PKU Muhamadiyah Yogyakarta. (Skripsi tidak dipublikasikan). Fakultas Psikologi Universitas Wangsa Manggala, Yogyakarta.

Parkes, L.P. \& Langford, P. H. (2008). Work-life balance of worklife alignment, a test of the importance of work-life balance for employee engagement and intention to stay in organizations. Journal of Management \& Organization, 14(1), 267-284.

Putra, A.A.N.A.A.P.W. (2013). Perbedaan antara motivasi kerja orang Bali yang bekerja di Bali dengan orang Bali yang merantau. (Skripsi tidak dipublikasikan). Program Studi Psikologi Universitas Udayana, Denpasar.

Peraturan Menteri Kesehatan Republik Indonesia No.17 Tahun 2013.

Ruwaida, A., Lilik, S., \& Dewi, R. (2006). Hubungan antara kepercayaan diri dan dukungan keluarga dengan kesiapan menghadapi masa menopause. Jurnal Indigenous, 8(2), 7699.

Robbins, S.P. \& Judge, T. A. (2008). Perilaku organisasi (Alih bahasa : Diana Angelica, Ria Cahyani dan Abdul Rosyid). Jakarta: Salemba Empat.

Rahmadita, I. (2013). Hubungan antara konflik peran ganda dan dukungan sosial pasangan dengan motivasi kerja pada karyawati di Rumah Sakit Abdul Rivai-Berau. Ejournal Psikologi Fisip Unmul , 1(1), 58-68.

Ruwanti, E., \& Jacobus, O.A. (2013). Konflik antara pekerjaan dan keluarga serta stress kerja terhadap kinerja perawat wanita pada Rumah Sakit Bethesda Yogyakarta. Forum Ilmiah, 10(1), $81-89$.

Santoso, S. (2003). Mengatasi berbagai masalah statistik dengan SPSS versi 11.5. Jakarta: PT. Elex Media Komputindo.

Sunasri, A.A. (2003). Konflik peran wanita bekerja di Desa Pemecutan Kaja Kota Denpasar. (Tesis tidak dipublikasikan). Program Kajian Budaya Universitas Udayana, Denpasar.

Suryani, L., K. (2003). Perempuan Bali Kini, Bali Post: Denpasar.

Suyadnya, I. W. (2009). Balinese woman and identities: are they trapped in traditions, globalization or both ?. Diunduh dari : http://journal.unair.ac.id/filerPDF/01Balinese_Women_and_identities.pdf.

Soeharto, T.N.E.D. (2010). Konflik pekerjaan-keluarga dengan kepuasan kerja : Metanalisis. Jurnal Psikologi, 37 (1), 189 194. 
Sarafino, E. P., \& Smith, T.W. (2011). Health psychology. Biopsychosocial interactions (7th ed.). River Street: John Wiley \& Sons, Inc.

Sugiyono. (2012). Metode penelitian bisnis. Bandung: Alfabeta.

Sarwono, J. (2013). Statistik multivariat aplikasi untuk riset skripsi. Yogyakarta: Andi Offset.

Susanti, S., \& Ekayati, I.,N. (2013). Peran pekerjaan, peran keluarga dan konflik pekerjaan pada perawat wanita. Persona Jurnal Psikologi Indonesia. 2(2), 183 -190.

Sugiyono. (2014). Metode penelitian pendidikan (Pendekatan kuantitaif, kualitatif, dan R\&D). Bandung: Alfabeta.

Taylor,. S.E. (2003). Health psychology (5th ed.). New York: McGraw-Hill Companies, Inc.

Triaryati, N. (2003). Pengaruh adaptasi kebijakan mengenai workfamily conflict issue terhadap absen dan turnover. Jurnal Manajemen \& Kewirausahaan, 5(1), 85-96.

Taylor, Shelley E., Peplau, L., A., \& Sears, David O. (2009). Psikologi sosial (Edisi 12) (terjemahan: Tri Wibowo B.S.). Jakarta: Kencana Prenada Media Grup.

Wedari, N. K. S. (2006). Perubahan identitas perempuan Bali dalam usaha batu bata di Desa Keramas : Sebuah kajian budaya. (Tesis tidak dipublikasikan). Program Magister Program Studi Kajian Budaya Universitas Udayana, Denpasar.

Yudiatmaja, F. (2013). Analisis regresi dengan menggunakan aplikasi komputer statistik SPSS. Jakarta: PT. Gramedia Pustaka Utama.

Zaidin, A. (2001). Dasar-dasar keperawatan profesional. Jakarta. Widya Medika Arikunto. 